Russian roulette
$\begin{aligned} & \text { Academy labs } \\ & \text { anxiously await } \\ & \text { reform proposal } \\ & \text { p887 }\end{aligned}$

\title{
Biologists seek consensus on guidelines for stem-cell research
}

\section{Erika Check, Washington}

How would you know if a human brain was trapped in a mouse's body?

That might sound like a question for science-fiction writers, not scientists. But prominent biologists discussed it at meeting at the US National Academies, held in Washington DC on 12-13 October, in an attempt to frame some ethical guidelines for research on human embryonic stem cells.

The academies plan to issue guidelines next February. And in the absence of any US government regulation of the expanding field - much of which is likely to be funded privately, owing to restrictions on its public funding - the suggestions are set to play a critical role in determining what experiments are done with stem cells.

Researchers at the meeting agreed on a lot: that the use of human embryonic stem cells to produce a baby should be banned, for example, and that stem-cell researchers should adopt guidelines to reassure the public that their work is ethically sound. But they differed on how to handle chimaeras, which mix cells and DNA from different species.

Many researchers think they could gain insights into human development and disease by transferring human embryonic stem cells into embryos, fetuses or newborn animals of other species. But the research poses uncomfortable questions about the boundary between man and mouse - or human and monkey, dog or sheep.

Irving Weissman, a cancer biologist who leads the privately funded Institute for Cancer/Stem Cell Biology and Medicine at Stanford University in Palo Alto, California, said that human-to-mouse stem-cell transplants have already proved invaluable to medicine. By seeding developing mice with human embryonic stem cells carrying genetic predispositions to disease, Weissman said, scientists could study how such diseases develop in animals. "Every level of research I do on stem and progenitor cells is enriched by making human-mouse chimaeras," he said, adding that much of it was "only possible" using the chimaeras.

Scientists could even construct a mouse whose entire brain was made of human-

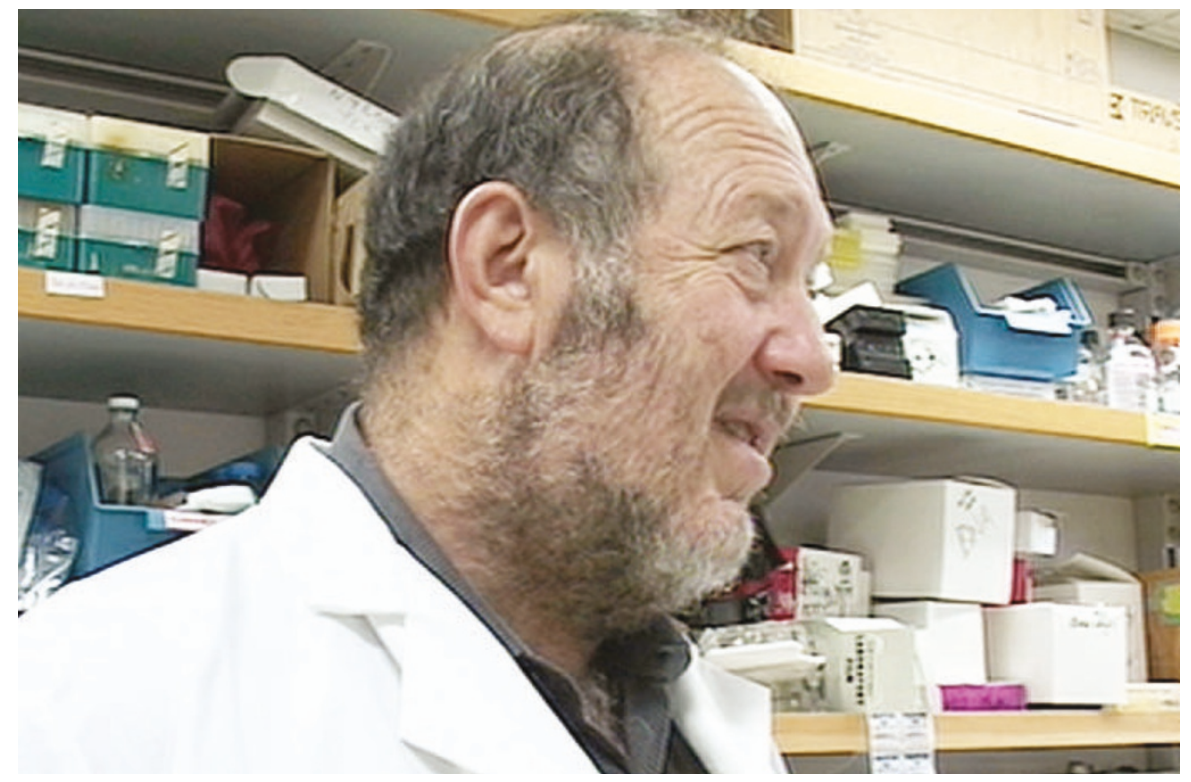

Mixed blessing: Irving Weissman supports experiments using chimaeras of human and mouse cells.

derived cells, Weissman said, although he has not performed such an experiment.

But others were concerned at the idea of a mouse with human brain cells. Brigid Hogan, a developmental biologist at Duke University in Durham, North Carolina, said that such research is troubling from an animal-welfare perspective, and becomes more so as the mouse brain becomes more human-like. She proposed that researchers adopt a scheme in which experiments would be allowed, disallowed, or merit "deeper scrutiny".

\section{Order sought}

"What I would like to see is some sort of hierarchy of regulation for experiments in which a large proportion of neuronal centres of the brain were going to be derived from human cells," Hogan said. "I would like to see evidence that those experiments could not be done in any other way."

Weissman disagreed, saying that he had not heard a good argument for any ban. "I'm not saying we should be unrestricted," he said. "But I haven't heard the reason yet for restricting certain experiments." Weissman said, for instance, that the 'yuck factor' is no reason to ban an experiment - but that health dangers to mother and child could justify a ban on reproductive cloning.

Other researchers proposed that scientists set up a body similar to the Recombinant DNA Advisory Committee, which is run by the US National Institutes of Health (NIH), to review questions on stem-cell research. But it is not clear where such a body would be located. The NIH washed its hands of much stem-cell research after President Bush decided not to publicly fund work on cells derived after 9 August 2001. And the research is too far from the clinic for the US Food and Drug Administration to get involved. That leaves a hole for scientists, who are not sure what the law permits them to do, and lack guidance on their work's impact on public opinion.

The stem-cell committee is co-chaired by cell biologist Richard Hynes of the Massachusetts Institute of Technology and bioethicist Jonathan Moreno of the University of Virginia. Its recommendations will not belaw, but Len Zon, president of the International Society for Stem Cell Research, said his group will help spread them through the scientific community. "If posed in the right way, they would actually speed the research," Zon said. 